Kronik Hemodiyaliz Hastalarında Vitamin D Düzeyi ile Hemodiyaliz Yeterliliği, İnflamasyon ve Kan Basıncı Arasındaki ìlişki

\title{
The Relationship Between Vitamin D Level and Hemodialysis Adequacy, Inflammation and Blood Pressure in Chronic Hemodialysis Patients
}

\section{Eda Altun}

Gölcük Necati Çelik Devlet Hastanesi, Nefroloji Bölümü, Kocaeli, Türkiye

\section{$\ddot{O} Z$}

GíRiŞ ve AMAÇ: Vitamin D eksikliği önemli bir halk sağll̆̆g sorunu olup diyaliz hastalarında bu durum daha siktır ve infeksiyon, anemi, kardiyovasküler hastalık gibi önemli problemlerle birliktelik göstermektedir. Çalışmanın amacı hemodiyaliz hastalarında vitamin D düzeyi ile hemodiyaliz yeterliliği, anemi, inflamasyon belirteçleri ve kan basincl düzeyleri arasındaki ilişkiyi incelemektir.

YÖNTEM ve GEREÇLER: Rutin hemodiyaliz (3X4 saat/hafta) programindaki 81 hasta (39 erkek (\%48.1) retrospektif olarak değerlendirildi. Kan basincl, fizik muayene bulguları giriş çıkış ağırlıkları kaydedildi. Biyokimya testleri, tam kan sayım,$C$ - reaktif protein (CRP), eritrosit sedimentasyon hizl (ESR), ferritin, parathormon (PTH) ve 25 OH Vitamin D (Vit D) düzeyleri dosyalart incelenerek kaydedildi. Diyaliz yeterliliği için Kt/V, URR hesapland.

BULGULAR: Hastaların \%98 inde vit D düzeyi düşük idi. Kt/ $V$ ile Vit $D$ düzeyi arasında istatistiksel anlamlı negatif korelasyon saptandı. ( $p=0.035)$ Kan basıncı düzeyi, ESR, CRP, hemoglobin düzeyi, serum PTH ve fosfor düzeyleri ile vit $D$ düzeyi arasında da ilişki gözlenmedi. ( $p>0.05$ hepsi için) Serum kalsiyum (Ca) düzeyi ile vit D düzeyi arasında anlamlı korelasyon saptandi. $p=0.048$

TARTIŞMA ve SONUÇ: Hemodiyaliz programındaki hastalarımızın \%95 den fazlasında $250 H$ vitamin D düzeyleri düşüktü. 1-25 OH vitamin D tedavisi uygulanan bu hastalarda diğer çalışmalardan farklı olarak iliş̧i olmaması veya Kt/V ile $25 \mathrm{OH}$ vitamin D arasında ters ilişsi bulunması ölçümlerin ilkbahar döneminde yapılmış olması ve $25 \mathrm{OH}$ Vitamin $D$ düzeyi ölçmemiz nedeni ile olabileceği söylenebilir. Normal sinırlarda vitamin D düzeyi olan hastaların, prediyaliz dönemde vit D ile tedavi edilmiş idi. Diyaliz hastaları ve kronik böbrek hastalarında vitamin D3'ün daha uygun takviyesi düşünülmeli ve bu konu ile ilgili daha kapsamlı ve geniş ölçekli çalışmalar yapılmalıdır.

Anahtar Kelimeler: hemodiyaliz, vitamin D, inflamasyon, kan basincl

\begin{abstract}
INTRODUCTION: Vitamin D Deficiency is an important public health problem and is more prevalent in dialysis patients. It is associated with important problems such as infection, anemia and cardiovascular disease. The purpose of the study is to investigate the relationship between vitamin $D$ levels and hemodialysis adequacy, anemia, inflammatory markers and blood pressure levels in hemodialysis patients.
\end{abstract}

METHODS: Eighty-one patients (39 male) undergoing hemodialysis (3x4 hours/week) were evaluated retrospectively. Their physical examination findings, pre- and post-dialysis weights, complete blood cell count, $C$-reactive protein $(C R P)$, erythrocyte sedimentation rate (ESR), ferritin, parathormone (PTH) and $25 \mathrm{OH}$ Vitamin D (Vit D) levels were recorded. $K t / V$ and URR were calculated for dialysis adequacy.

RESULTS: Ninety-eight percent of the patients had a low level of vitamin D. A statistically significant negative correlation was found between $K t / V$ and viamint $D$ level $(p=0.035)$. No relationship was determined between vitamin $D$ level and blood pressure, ESR, CRP, hemoglobin, serum PTH and phosphorus levels, $(p>0.05$ for all). A significant correlation was found between serum calcium $(\mathrm{Ca})$ level and vitamin $D$ levels ( $p=0.048$ ).

DISCUSSION AND CONCLUSION: The $25 \mathrm{OH}$ vitamin D level was found low in more than 95\% of our hemodialysis patients. Negative correlation between serum vitamin $D$ and $K T / v$ may be due to the fact that serum $25 \mathrm{OH}$ vitamin $\mathrm{D}$ was measured instead of serum 1-25 $(\mathrm{OH}) 2$ vitamin $D$ and in spring. So that it may be more appropriate measuring serum level of 1-25 $(\mathrm{OH}) 2$ vitamin $\mathrm{D}$, to assess the vitamin D status of dialysis patients treated with calcitriol

Keywords: hemodialysis, vitamin D, inflammation, blood pressure

İletişim / Correspondence:

Dr. Eda Altun

Gölcük Necati Çelik Devlet Hastanesi, Nefroloji Bölümü, Kocaeli, Türkiye

E-mail: dredaaltun@hotmail.com

Başvuru Tarihi: 03.07.2018

Kabul Tarihi: 16.04.2019 


\section{INTRODUCTION}

Vitamin D is known to be biologically inactive and converted into 1,25 dihydroxy vitamin $\mathrm{D}$ by hydroxylation in the kidney and liver. The most important factors in renal regulation of Vitamin D synthesis are PTH and phosphorus levels $(1,2)$.

According to the KDOQI guidelines, if $25(\mathrm{OH}) \mathrm{D} 3$ level in the circulation is lower than $5 \mathrm{ng} / \mathrm{ml}$, then it is considered as severe vitamin D deficiency; if it is between $5-15 \mathrm{ng} / \mathrm{ml}$, it is considered as mild vitamin D deficiency; if it is between $15-29 \mathrm{ng} / \mathrm{ml}$, it is considered as vitamin D deficiency; if it is higher than $30 \mathrm{ng} / \mathrm{ml}$, it is considered as normal vitamin D level; if it is more than $150 \mathrm{ng} / \mathrm{ml}$, it is considered as vitamin $\mathrm{D}$ intoxication. If $25(\mathrm{OH}) \mathrm{D} 3$ levels are below $30 \mathrm{ng} / \mathrm{ml}$, vitamin D2 (ergocalciferol) replacement treatment is suggested (3).

Inflammation is an important risk factor in general public and patients with chronic kidney disease with respect to cardiovascular diseases and mortality $(4,5)$. The uremia itself and the exposure of the blood to dialysate and dialysis membrane in the extracorporeal circulation during dialysis can stimulate the release of inflammatory cytokines (4). A significant relationship was observed between high CRP levels and increased mortality risk of hemodialysis patients (5). It was found that low hemoglobin levels in chronic kidney patients had negative effects on cardiovascular mortality, frequent admission to hospital, and left ventricular hypertrophy. Inflammation is also a proven risk factor that causes anemia for dialysis patients.

Vitamin D was found to inhibit antigenpresenting cell maturation, angiogenesis and vascular smooth muscle cell proliferation. Vitamin D has effect on up-regulation of nuclear factor-Kappa beta activity and IL-10, and down-regulation of IL$6, \mathrm{IL}-12, \mathrm{IFN}-\gamma$ and TNF- $\alpha$. Due to these effects on cytokine profile Vit $\mathrm{D}$ is effective on reducing inflammation.

Hemodialysis adequacy is used in a broader sense today, covering all excretory and endocrine functions of kidney. However, it is traditionally defined as dialysis dose that is measured by solute removal. Methods such as single-pool $\mathrm{Kt} / \mathrm{V}$, urea reduction ratio are used to determine the dialysis adequacy for hemodialysis patients. As long as there is no significant residual renal function, it is suggested that dialysis should last at least 3 times per week and at least 12 hours. The target $\mathrm{eKt} / \mathrm{V}$ is accepted as at least 1.2 for anuric patients, 1.4 for female and patients with comorbidity $(6,7)$.

The purpose of the present study is to find out whether there is a significant relationship between vitamin D levels and CRP, sedimentation rate, anemia, blood pressure levels and dialysis adequacy in hemodialysis patients.

\section{MATERIAL AND METHODS:}

\section{Patients:}

81 chronic hemodialysis patients were included in the study. The criteria for the inclusion to study are as follows: 1. Dialysis duration $>3$ months, 2 . Not having an acute infection, clinically apparent heart and hepatic failure, acute coronary syndrome, cerebrovascular event, 3. Not having blood transfusion, 4 . Not having a known malign disease or tuberculosis, 5. Fresenius $4008 \mathrm{~S}$ and $4008 \mathrm{~B}$ hemodialysis machines, standard heparinization and Fresenius high-flux dialyzer (150-190) with a synthetic polynephron structure and an effective surface area of $1.6-2.1 \mathrm{~m} 2$ were used. All patients were dialyzed through arteriovenous fistulas with a blood flow $>300 \mathrm{ml} /$ minute. The diet recommended for the patients included $1.2 \mathrm{gr} / \mathrm{kg}$ protein, $4 \mathrm{gr} / \mathrm{NaCl}$, 2 gr potassium, $600 \mathrm{mg}$ phosphorus, $1000 \mathrm{mg}$ calcium. Also, oral B complex vitamin and levocarnitine 3 grams/week were used. Patients were treated with essential amino acid, oral phosphorus binders, active D vitamin (calcitriol) antihypertensive therapy and IV/subcutaneous erythropoietin according to results of monthly laboratory tests and clinical follow-up.

The following formulas were used for KT calculations of $\mathrm{Kt} / \mathrm{V}$ and residual kidney function. $\mathrm{R}=$ Post-dialysis BUN/pre-dialysis BUN,

$\mathrm{URR}=100 \times(1-\mathrm{R})$,

$\mathrm{PRU}=($ pre-dialysis BUN- Post-dialysis $\mathrm{BUN}) /$ predialysis BUN

$\mathrm{Kt} / \mathrm{V}($ Jindal $)=(0.04 \times \mathrm{PRU}) \tilde{n} 1$.

$2 \mathrm{Kt} / \mathrm{V}$ (Daurgidas) $=\mathrm{In}(\mathrm{R}-0.03-0.75 \times \mathrm{UF} / \mathrm{W})$

UF: Ultrafiltrate (as/in L), W: post-dialysis weight (in $\mathrm{kg}$ )

\section{Statistical Analysis:}

Statistical analyses were conducted by using SPSS (Statistical Package for Social Science) for 
Windows Version 10.0. Results were expressed as mean \pm SD. $p<0.05$ value was accepted as statistically significant.

\section{RESULTS}

The characteristics and laboratory parameters of the patients are summarized in table 1. It was found that $17,3 \%$ of our patients had severe vitamin D deficiency, $74,1 \%$ had moderate vitamin $\mathrm{D}$ deficiency, 6,2\% had vitamin D deficiency, 2,5\% had normal vit $\mathrm{D}$ levels. Female patients had lower vitamin $\mathrm{D}$ levels comparing to male patients $(\mathrm{p}=0,0001)$

\begin{tabular}{|c|c|c|}
\hline & $\begin{array}{l}\text { Mean } \pm \text { Std. } \\
\text { Dev }\end{array}$ & $\begin{array}{l}\text { Median (min - } \\
\max )\end{array}$ \\
\hline $\begin{array}{l}\text { Vitamin D } \\
(\mathrm{ng} / \mathrm{ml}, 6,2-55)\end{array}$ & $9.73 \pm 7.34$ & $8(2.53-47)$ \\
\hline $\mathrm{Kt} / \mathrm{V}$ & $1.55 \pm 0.25$ & $1.48(1.09-2.33)$ \\
\hline $\begin{array}{l}\text { Sedimentation rate } \\
\text { h1zı } \\
(\mathrm{ESR}, \mathrm{mm} / \mathrm{h})\end{array}$ & $49.56 \pm 23.95$ & $48(10-142)$ \\
\hline $\begin{array}{l}\text { C-reactive Protein } \\
(0-0,5) \mathrm{mg} / \mathrm{dl}\end{array}$ & $1.39 \pm 1.96$ & $0.76(0.03-9.63)$ \\
\hline $\begin{array}{l}\text { Ferritin } \\
(22-330 \mathrm{ng} / \mathrm{ml})\end{array}$ & $617.01 \pm 420.41$ & $499.64(17-2000)$ \\
\hline $\begin{array}{l}\text { Hemoglobin } \\
(11-18 \mathrm{~g} / \mathrm{dl})\end{array}$ & $11.37 \pm 1.77$ & $11.1(7.66-17.8)$ \\
\hline $\begin{array}{l}\text { Pre-dialysis systolic } \\
\text { Blood Pressure } \\
(\mathrm{mmHg})\end{array}$ & $145.19 \pm 30$ & $150(80-220)$ \\
\hline $\begin{array}{l}\text { Pre-dialysis diastolic Blood } \\
\text { Pressure } \\
(\mathrm{mmHg})\end{array}$ & $83.09 \pm 16.44$ & $85(50-180)$ \\
\hline $\begin{array}{l}\text { Post-dialysis systolic } \\
\text { Blood Pressure systolic } \\
(\mathrm{mmHg})\end{array}$ & $112.47 \pm 24.53$ & $110(70-190)$ \\
\hline $\begin{array}{l}\text { Post-dialysis diastolic } \\
\text { Blood Pressure (mmHg) }\end{array}$ & $70.8 \pm 11.98$ & $70(40-100)$ \\
\hline $\begin{array}{l}\text { Parathormon } \\
(10-72 \mathrm{pg} / \mathrm{ml})\end{array}$ & $411.14 \pm 439.55$ & $282(0.9-2537)$ \\
\hline $\begin{array}{l}\text { Calcium } \\
(8,6-10,2 \mathrm{mg} / \mathrm{dl})\end{array}$ & $9.08 \pm 0.75$ & $9(7.5-11.2)$ \\
\hline $\begin{array}{l}\text { Phosphorus } \\
(2,5-4,5 \mathrm{mg} / \mathrm{dl})\end{array}$ & $5.08 \pm 1.45$ & $5(2.51-8.29)$ \\
\hline Age (years) & $61.35 \pm 16.43$ & $65(18-91)$ \\
\hline $\begin{array}{l}\text { Duration of treatment } \\
\text { (month) }\end{array}$ & $58.77 \pm 39.43$ & $56(6-174)$ \\
\hline
\end{tabular}

A statistically significant negative correlation was found between $\mathrm{Kt} / \mathrm{V}$ and vitamin D levels (p: $0,035)$. When diabetic patients were compared to non-diabetic patients, no statistically significant correlation was found between $\mathrm{Kt} / \mathrm{V}$ level and vitamin D level in each group (p:0,377) (Figure 1).

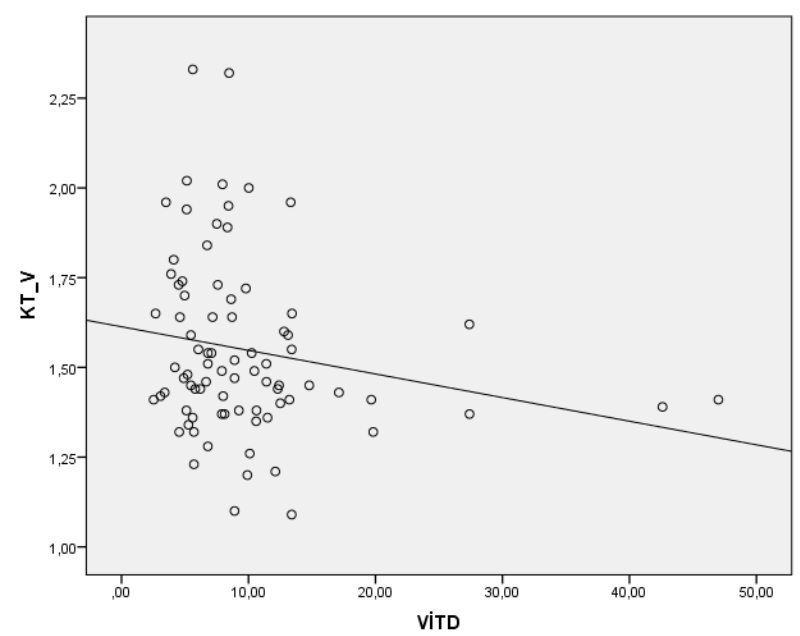

Figure 1. Relationship between Vit D level and Kt-V

The mean erythrocyte sedimentation rate in all the groups of patients was found to be $49.56 \pm 23.95$ $\mathrm{mm} / \mathrm{h}$, and it was higher in diabetic patients $(54.96 \pm$ $22.34 \mathrm{~mm} / \mathrm{h}$ ). However, there was no statistically significant difference (p: 0,585). No relationship was found between CRP, defined as inflammatory markers, and sedimentation rate and vitamin D level (p: 0.242-0.564)

No statistically significant ratio was found between vitamin $\mathrm{D}$ level and CRP, erythrocyte sedimentation rate and ferritin levels (p: 0,242, p: 0,564, p: 0,542 respectively) (Figure 2). CRP levels in diabetic patients was $0,84 \mathrm{mg} / \mathrm{dl}$, while it was 0.7 $\mathrm{ml} / \mathrm{dl}$ in non-diabetic patients. However, there was no statistically significant difference between diabetic group and non-diabetic group $(\mathrm{p}=0,528)$.

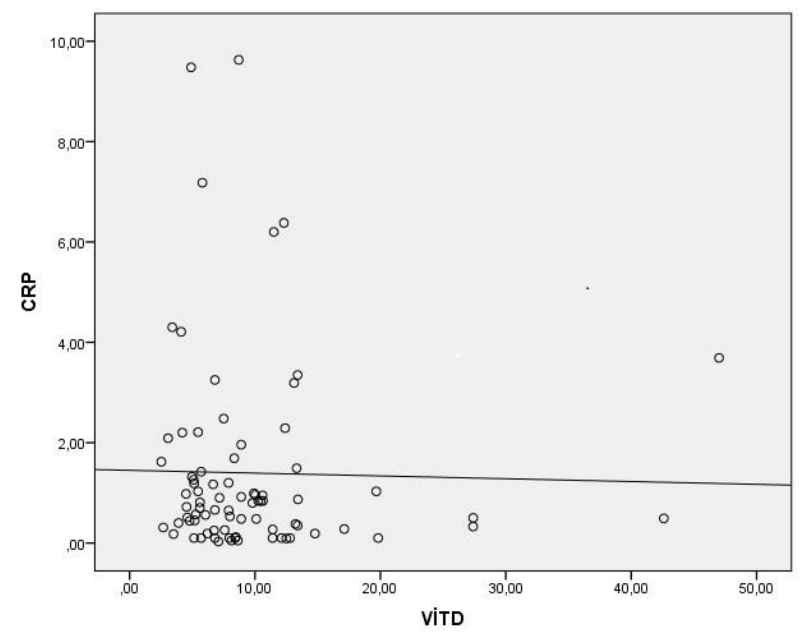

Figure 2. Relationship between Vit D level and CRP 


\begin{tabular}{|c|c|c|c|c|}
\hline & Diabetes Mellitus & Mean \pm Std. Dev & Median (min - max) & $\mathrm{p}$ \\
\hline \multirow[t]{2}{*}{ Vitamin D } & 1 & $10.68 \pm 8.68$ & $8.45(3.07-47)$ & \multirow[t]{2}{*}{0.377} \\
\hline & 2 & $8.35 \pm 4.56$ & $7.5(2.53-27.39)$ & \\
\hline \multirow[t]{2}{*}{$\mathbf{K t} / \mathbf{V}$} & 1 & $1.58 \pm 0.27$ & $1.47(1.1-2.33)$ & \multirow[t]{2}{*}{0.58} \\
\hline & 2 & $1.51 \pm 0.21$ & $1.49(1.09-2.02)$ & \\
\hline \multirow[t]{2}{*}{ ESR } & 1 & $46.78 \pm 21.44$ & $49(10-96)$ & \multirow[t]{2}{*}{0.585} \\
\hline & 2 & $54.33 \pm 27.62$ & $48(10-142)$ & \\
\hline \multirow[t]{2}{*}{ CRP } & 1 & $1.5 \pm 2.28$ & $0.7(0.03-9.63)$ & \multirow[t]{2}{*}{0.528} \\
\hline & 2 & $1.24 \pm 1.4$ & $0.84(0.05-7.18)$ & \\
\hline \multirow[t]{2}{*}{ Ferritin } & 1 & $672.45 \pm 462.03$ & $529.5(17-2000)$ & \multirow[t]{2}{*}{0.198} \\
\hline & 2 & $536.38 \pm 342.08$ & $\begin{array}{l}460.27(77.51- \\
1636.74)\end{array}$ & \\
\hline \multirow[t]{2}{*}{$\mathrm{Hb}(\mathrm{g} / \mathrm{dl})$} & 1 & $11.29 \pm 1.91$ & $11.1(7.66-17.8)$ & \multirow[t]{2}{*}{0.57} \\
\hline & 2 & $11.48 \pm 1.57$ & $11.2(9.27-14.9)$ & \\
\hline \multirow{2}{*}{$\begin{array}{l}\text { Pre-dialysis systolic Blood } \\
\text { Pressure (mmHg) }\end{array}$} & 1 & $142.5 \pm 30.42$ & $140(80-210)$ & \multirow[t]{2}{*}{0.262} \\
\hline & 2 & $149.09 \pm 29.41$ & $150(80-220)$ & \\
\hline \multirow{2}{*}{$\begin{array}{l}\text { Pre-dialysis diastolic Blood } \\
\text { Pressure (mmHg) }\end{array}$} & 1 & $83.13 \pm 18.84$ & $80(60-180)$ & \multirow[t]{2}{*}{0.336} \\
\hline & 2 & $83.03 \pm 12.43$ & $90(50-100)$ & \\
\hline \multirow{2}{*}{$\begin{array}{l}\text { Post-dialysis systolic Blood } \\
\text { Pressure (mmHg) }\end{array}$} & 1 & $109.38 \pm 22.56$ & $105(70-180)$ & \multirow[t]{2}{*}{0.173} \\
\hline & 2 & $116.97 \pm 26.87$ & $110(70-190)$ & \\
\hline \multirow{2}{*}{$\begin{array}{l}\text { Post-dialysis diastolic Blood } \\
\text { Pressure (mmHg) }\end{array}$} & 1 & $69.48 \pm 12.34$ & $70(40-100)$ & \multirow[t]{2}{*}{0.188} \\
\hline & 2 & $72.73 \pm 11.33$ & $70(40-90)$ & \\
\hline
\end{tabular}

It was also found that there was no statistically significant correlation between hemoglobin level and vitamin D level (p: 0,472). While a statistically significant relationship was found between serum vitamin D and serum Ca level (p: 0,048), no significant relationship were found with PTH and phosphorus levels (p: 0,555, p: 0,096).

When vit $\mathrm{D}$ level and pre- and post-dialysis blood pressure levels were compared, it was found that there was no significant correlation. When blood pressure levels were compared between diabetic and non-diabetic patients, it was found that there was a statistically significant correlation between predialysis systolic blood pressure and vit $\mathrm{D}$ level in diabetic patients (p: 0.034). It was observed that there was no significant relationship between serum albumin level and vit D level (Table 2).

\section{DISCUSSION}

The level of vitamin D in our patients was quite low as other studies. Only \% 2.5 patients had normal vit $\mathrm{D}$ level. Also female patients comparing to male had significantly low vitamin D. Diabetic patients had no significantly lower levels according to nondiabetic patients. Taşkapan et al, in their study with 273 peritoneal dialysis (PD) patients in Turkey and Greece, reported that more than $95 \%$ of the patients had low vitamin D level. It was found that our patients with normal vitamin D level were treated with vitamin $\mathrm{D}$ during non-dialysis period.

Recently it has been shown that there is an improvement in morbidity and mortality in dialysis patients with high $\mathrm{Kt} / \mathrm{V}$ values. It was seen that as the $\mathrm{Kt} / \mathrm{V}$ value increases, morbidity and mortality rates significantly decreased $(7,8)$. 
Charra et al., in their study in France, divided the patients in two groups as the ones with high $\mathrm{Kt} / \mathrm{V}(1.97 \pm 0.35)$ and those with low $\mathrm{Kt} / \mathrm{V}(1.35 \pm 0.16)$, and found that those with high $\mathrm{Kt} / \mathrm{V}$ value lived longer (9). The mean $\mathrm{Kt} / \mathrm{V}$ value of our patients were found to be $1,5 \pm 0,4$. In our study it was found that a statistically significant negative correlation was found between $\mathrm{Kt} / \mathrm{V}$ and vit $\mathrm{D}$ levels (p: -0,035). And also, when diabetic and nondiabetic patients were compared, no difference between the $\mathrm{Kt} / \mathrm{V}$ levels was observed.

There are studies that show vitamin D is associated with several diseases and that regular vitamin D supplement has potential effects on improving various pathophysiological events. Zimmerman et al, stated that CRP and albumin were independent indicators for all causes of death in HD patients. Again, there are also studies stating that high inflammatory markers in uremic patients (especially IL-6 and hsCRP) are independent and strong pre-determiners for cardiovascular morbidity and mortality (10). The mean CRP and erythrocyte sedimentation rate were found to be increased. As inflammatory markers CRP and erythrocyte sedimentation rate were not correlated with vit $\mathrm{D}$ level.

Wong et al. (11) showed that PTH levels of CKD patients were dependent on $25(\mathrm{OH}) \mathrm{D}$ levels, and they drew a plateau when $25(\mathrm{OH}) \mathrm{D}$ levels were over $30 \mathrm{ng} / \mathrm{ml}$. For this reason, it can be said that it reduces the risk of severe hyperparathyroidism when $25(\mathrm{OH}) \mathrm{D}$ level in the circulation is at least $30 \mathrm{ng} / \mathrm{ml}$ in CKD patients. It was observed that there was no significant correlation between vit D level and PTH level of our the patients

Melamed et al. (12), in a study they conducted with 13331 participants aged over 20, reported that as $25(\mathrm{OH}) \mathrm{D} 3$ levels decreased, mean systolic and diastolic blood pressure increased; mean body mass index, incidence of diabetes, proteinuria, serum $\mathrm{C}$ reactive protein level increased; and mean serum albumin levels decreased. Participants were monitored for an average of 8,7 years and in the group where vitamin D levels were found the lowest, mortality due to all reasons was found to increase 1.78 times. In our group of patients, no relationship was found between pre- and post-dialysis systolic/diastolic blood pressure levels and vit D.
Only statistically significant correlation was found between systolic blood pressure and vit $\mathrm{D}$ levels in our diabetic patients. Hemoglobin, serum albumin levels which determines dialysis adequacy, were also not correlated with vitamin D.

\section{CONCLUSION}

In conclusion, the $25 \mathrm{OH}$ vitamin $\mathrm{D}$ levels were found to be quite low in our hemodialysis patients when compared to the guideline suggestions. The 25 $\mathrm{OH}$ vit D level was found low in more than $95 \%$ of our hemodialysis patients. There was an inverse relationship between $\mathrm{Kt} / \mathrm{V}$ and $25 \mathrm{OH}$ vitamin $\mathrm{D}$. This may due to the fact that the measurements were done in spring and that we measured $25 \mathrm{OH}$ vitamin D level instead of serum 1-25 $(\mathrm{OH}) 2$ vitamin $\mathrm{D}$. There were not any correlation between Vitamin D levels and inflammatuar markers including erythrocyte sedimentation rate, CRP and albumin and hemoglobin levels. So that it may be more appropriate measuring serum level of 1-25 $(\mathrm{OH}) 2$ vitamin $\mathrm{D}$, to assess the vitamin $\mathrm{D}$ status of dialysis patients treated with calcitriol.

\section{REFERENCES}

1- Holick MF. High prevalence of vitamin D inadequacy and implications for health. Mayo Clin Proc 2006; 81:353-73.

2- Vieth R. What is the optimal vitamin D status for health? Prog Biophys Mol Biol 2006; 92:26-32.

3- Block GA, Port FK: Re-evaluation of risks associated with hyperphosphatemia and hyperparathyroidism in dialysis patients: Recommendations for a change in management. Am J Kidney Dis 2000; 35: 1226-1237

4- Mustafa Arıcı and John Walls. End-Stage Renal Disease, atherosclerosis, and cardiovascular mortality: Is C-reactive protein the missing link? Kidney International, Vol. 59 (2001), pp. 407-414.

5- Blancher $\mathrm{J}$ et al: Arterial calcifications, arterial stifness and cardiovascular risk in end stage renal disease. Hypertension.2001;38:938-42.

6- Blumenkrantz MJ. Nutrition. Handbook of dialysis.de. Eds. Daurgidas JT, Ings TS. (2nd ed). Boston, Little, Brown and Company, 1994; 374-400.

7- Lowrie, E.G., Lew, N.L. Death risk in hemodialysis patients:The predictive value of 
commonly measured variables and evaluation of death rate differences between facilities. Am J Kidney Dis 1990; 15: 458-482.

8- Lindsay RM, SpannerE, Heidenheim P, Kortas C, Blake PG. PCR, Kt/V and membrane Kidney Int 1993; 43 (suppl 41 ): 268-273.

9- Charra B, Calemard E, Ruffet M, Chazot C, Terrat JC, Vanel T, Laurent G. Survival as an index of adequacy of dialysis. Kidney Int 1992; 41: 12861261.

10-Stenvinkel P: Inflammatory and atherosclerotic interactions in the depleted uremic patient. Blood Purif 10:53-61, 2001.

11-Wong J,Tran J, Thomas D, Rosenblum S, Zazra JJ, Cain J,Holick MF: Hypovitaminosis D(HVD) exacerbates secondary hyperparathyroidism early in the course of chronic kidney disease . Proceedings of the Endocrin Society's 84th Annual Meetings, June 19-22,2002:2- 557

12-Melamed ML, Michos ED, Post W, Astor B: 25hydroxyvitamin $\mathrm{D}$ levels and the risk of mortality in the general population. Arch Intern Med 2008; 168 (15): 1629-1637. 